Research Article

\title{
Diarrhoea and Associated Clinical Features in Different Pathotypes of Diarrheagenic E. coli Isolated in Children: A Case-Control Study in a Tertiary Care Hospital
}

\author{
Monalisa Mohanty', Preetam Kumar Kar ${ }^{2}$, Biswabara Rout ${ }^{3}$, Tapas Ranjan Behera ${ }^{4}$ \\ ${ }^{1}$ Senior Resident, Department of Microbiology, AlIMS, Bhubaneswar, Odisha, India. \\ ${ }^{2,4}$ Assistant Professor, Department of Community Medicine, SCB Medical College, Cuttack, Odisha, India. \\ ${ }^{3}$ Assistant Professor, Department of Physiology, SCB Medical College, Cuttack, Odisha, India. \\ DOI: https://doi.org/10.24321/0019.5138.202165
}

\section{I $\quad \mathbf{N} \quad \mathbf{F} \quad \mathbf{O}$}

\author{
Corresponding Author: \\ Tapas Ranjan Behera, Department of Community \\ Medicine, SCB Medical College, Cuttack, Odisha, \\ India. \\ E-mail Id: \\ tapas4behera@gmail.com \\ Orcid Id: \\ https://orcid.org/0000-0003-3934-6546 \\ How to cite this article: \\ Mohanty M, Kar PK, Rout B, Behera TR. Diarrhoea \\ and Associated Clinical Features in Different \\ Pathotypes of Diarrheagenic $E$. coli Isolated in \\ Children: A Case-Control Study in a Tertiary Care \\ Hospital. J Commun Dis. 2021;53(3):250-258. \\ Date of Submission: 2021-07-08 \\ Date of Acceptance: 2021-09-19
}

\section{$\begin{array}{llllllll}\mathbf{A} & \mathbf{B} & \mathbf{S} & \mathbf{T} & \mathbf{R} & \mathbf{A} & \mathbf{C} & \mathbf{T}\end{array}$}

Background: Acute gastroenteritis remains to be a major health problem in children causing high morbidity and mortality In India, diarrhoea is the third most common cause of death in children younger than 5 years of age, with an estimation of 300,000 deaths each year. Diarrheagenic Escherichia coli (DEC) being one of the important bacterial agents, the present hospital-based study was done to enlighten on the occurrence of different pathotypes and clinical features associated with DEC related diarrhoea.

Methods: The case-control study was carried out in SCB Medical College, Odisha from October 2014 to September 2016 on the childhood diarrhoea cases ( $\leq 14$ years of age). Stool samples were collected and processed to isolate the causative bacterial agent by standard biochemical test, serotyping and multiplex PCR.

Results: 350 cases and 100 controls were included in the study. The different pathotypes of DEC were isolated significantly more in cases than control group ( $\mathrm{P}$ value $=0.0205$ ) with an isolation rate of $7.4 \%$ in cases. 12 (46.2\%) of DEC were in 0-1 year age group followed by 1-5 year of age group i.e. $11(42.3 \%)$ and least in $5-14$ years of age group i.e. $3(11.5 \%)$. The most common pathotype was Enterotoxigenic $E$. coli (ETEC) followed by Enteropathogenic E.coli (EPEC). Fever is the most common symptom associated with DEC diarrhoea; the other two common symptoms were watery diarrhoea and vomiting. Exclusive breastfeeding was the protective factor. Seasonal variation of DEC was found more among the cases in the rainy season.

Conclusion: Different pathotypes of DEC being associated commonly with childhood diarrhoea, the correct identification of various types of DEC along with the clinical knowledge is important to reduce the morbidity and mortality caused by it.

Keywords: DEC, Acute Gastroenteritis, Multiplex PCR, Exclusive Breastfeeding 


\section{Introduction}

Acute gastroenteritis continues to be one of the major health issues in children all over the world especially in developing countries and is responsible for high morbidity and mortality among children under 5 years of age. ${ }^{1}$ Diarrheal diseases can cause infection in up to 2.5 billion people and are responsible for about 1.5 million deaths each year. ${ }^{2-4}$ In children $<5$ years of age, $40 \%$ of the morbidity and $30 \%$ of the mortality are attributed to diarrheal disease. ${ }^{3,5}$ Diarrhoea is thte second most common cause of under 5 mortality globally following respiratory illness. ${ }^{6}$ The incidence and aetiology of diarrhoea are influenced by a number of factors like climate, geographical area, time of the year, cultural and socio-economic status, poor water supply, hygienic standards. Besides these, the individual's nutritional status, feeding habit, age and immunity play a special role. ${ }^{7}$ It acts as a major source of malnutrition and life-threatening complications. ${ }^{8,9}$ In India, diarrhoea is the third most common cause of death among children less than 5 years of age, with an estimation of 300,000 death each year. ${ }^{10}$ The three states Madhya Pradesh, Odisha and Tamil Nadu together constitute the highest percentage of children suffering from diarrhoea in India. ${ }^{11} \mathrm{~A}$ broad range of microorganisms such as viruses particularly Rotavirus, parasites and bacteria are associated with diarrhoea in children. ${ }^{3,12}$ In India, Rotavirus attributes to about 11.37 million episodes of acute gastroenteritis (AGE) annually in children $<5$ years of age. ${ }^{13} \ln 2011$, it is estimated that rotavirus associated AGE caused 78,000 deaths among children in India and majority (75.6\%) of them were among children less than 2 years. ${ }^{13}$ Two oral rotavirus vaccines, Rotarix (RV1; monovalent G1P; ${ }^{8}$ GlaxoSmithKline Biologicals, Belgium) and RotaTeq (RV5; pentavalent G1, G2, G3, G4, P, Merck Vaccines, NJ, USA) have been commercially available in India since 2006 to prevent rotavirus associated AGE. ${ }^{14,15}$ In 2015, another indigenously developed vaccine named as the ROTAVAC vaccine (Bharat Biotech, India), containing the live $116 \mathrm{E}$ rotavirus strain (G9P), ${ }^{11}$ was introduced at a substantially lower price. ${ }^{13}$ In April 2016, the Government of India included the vaccine in the Universal Immunization Programme (UIP) in 4 states (Andhra Pradesh, Haryana, Himachal Pradesh, Odisha) with the subsequent inclusion of 5 more additional states by September 2017 (Rajasthan, Madhya Pradesh, Assam, Tripura, Tamil Nadu). With the implementation of this vaccine, there is a reduction in both mortality and morbidity in the paediatric age group due to Rotavirus associated AGE. ${ }^{16}$

Among the bacterial agents, diarrheagenic Escherichia coli are one of the most frequently detected pathogens worldwide. ${ }^{17,18} \mathrm{E}$. coli is also the predominant nonpathogenic facultative anaerobic member of the human intestinal microflora and colonizes in the gastrointestinal tract of new-born within few hours just after birth and can be readily isolated from faecal samples. ${ }^{19}$ However, some E. coli strains have developed the ability to cause diseases of gastrointestinal, urinary and central nervous system in the human host. ${ }^{20,21}$ Diarrheagenic Escherichia coli (DEC) roughly accounts for $30-40 \%$ of acute episodes of diarrhoea in children $<5$ years of age in developing countries ${ }^{22}$ and is also responsible for both sporadic cases and outbreaks of diarrhoea throughout the world. ${ }^{23}$ Diarrheagenic strains of $E$. coli are divided into 6 main categories on the basis of distinct epidemiological and clinical features, specific virulence determinants and association with certain serotypes. $^{24,25}$ These include enteropathogenic E. coli (EPEC), enterotoxigenic $E$. coli (ETEC), enteroinvasive E. coli (EIEC), enterohaemorrhagic E. coli (EHEC) or Shiga-toxin producing E. coli (STEC), enteroaggregative E. coli (EAEC) and diffusely adherent $E$. coli (DAEC) ${ }^{25}$

Though different strains of DEC are responsible for a substantial proportion of childhood diarrhoea, due to lack of routine diagnostic procedure and paucity of epidemiological data lead to its misidentification. ${ }^{1}$ With the above background, the present hospital-based study is conducted to know the pathotypes of DEC diarrhoea and factors predisposing to the infection with DEC in children.

\section{Materials and Methods}

The study was a hospital-based prospective case-control study, with a duration of 2 years from October 2014 to September 2016. It was conducted in SCB medical college and hospital. Children less than 14 years of age with diarrhoea, characterised by stools with decreased consistency and increased volume because of imbalance of secretion and absorption of water and salts in the intestine who attended the OPD and were admitted to the indoor Paediatric department of SCB were included as cases. ${ }^{26}$ Samples from patients who received antibiotics before admission or during their hospital stay were excluded from the study. The control group included children who had not had diarrhoea in the preceding 2 weeks and they were also age-matched with that of case group children. Selection bias is overcome by taking controls from the same setting (same hospital) and by age matching. All cases admitted to the indoor paediatric ward are included. As many patients (children) are being referred here after receiving some first-hand treatment at other hospitals (which includes antibiotics), hence the children who have not received any antibiotic therapy were only included. Approval (IEC/ IRB No: 418/18.2.17) for the work was taken from the Institutional Ethical Committee.

Children of the same age group are taken as controls from the same hospital having other diseases during the same time period to eliminate the confounding factor of age. Children with diarrhoea, characterised by the occurrence of 
3 or more loose, liquid or watery stools or at least 1 bloody stool in a 24 hour period were taken as cases. Samples from patients who received antibiotics before admission or during their hospital stay were excluded. Children who had not had diarrhoea in the preceding 2 weeks were taken as control population and were age-matched. After fulfilling the inclusion and exclusion criteria, simple random sampling method was used to get the cases.

\section{Patient Work-up}

After the selection of cases, a detailed history was obtained and different demographic data such as age, sex, clinical presentations, length of hospital stay and antibiotic history were obtained from patients or from their guardians. Stool samples were collected in the universal container after getting consent and were processed for the identification of the etiological agent.

\section{Microbiological Work-up}

On the first day, wet mount was performed to screen for the presence of leucocytes, RBC, ova and cysts of parasites. The rest of the stool samples from both cases and controls were inoculated in suitable growth media to isolate and identify the bacterial isolates. ${ }^{27} \mathrm{~A}$ single pure colony was isolated from different selective media such as MacConkey agar,
DCA agar and TCBS agar etc. after overnight incubation at $37^{\circ} \mathrm{C} \&$ grown and subsequently subjected to the standard biochemical and serological tests for the identification bacteria causing diarrhoea. ${ }^{27}$ The $E$. coli isolated from samples were subjected to serotyping methods (using Denka Seiken Co; Ltd., Tokyo, Japan antisera) and multiplex PCR for the identification of different pathotypes of DEC (Table 1). ${ }^{28}$

\section{Statistical Data Analysis}

The statistical analysis was done by using Chi-square table and SPSS 19 software. The $p$ value of less than 0.05 was considered as significant. For all the statistical analyses, PCR was considered as gold standard method.

\section{Results}

Out of 350 cases, bacterial and parasitic cysts and ova are detected in 270 (77.1\%) samples, of these bacterial isolates, 245 (70\%) were E. coli, 3 (0.8\%) Vibrio cholerae and 2 (0.6\%) were Shigella species. Among the parasitic pathogens, cysts of Giardia lamblia were detected in 10 (2.9\%) and ova of Ancyclostoma duodenale and Ascaris lumbricoides were detected in $6(1.7 \%)$ and $4(1.1 \%)$ respectively. Out of 100 controls E. coli. was isolated in $30(30 \%)$ cases only (Table 2$)$.

Table I.List of PCR Primer Used in the Study

\begin{tabular}{|c|c|c|c|c|c|}
\hline S. No. & DEC & Gene & Sequence $\left(5^{\prime}-3^{\prime}\right)$ & Amplicon Size & Annealing Temperature $\left({ }^{\circ} \mathrm{C}\right)$ \\
\hline 1. & ETEC & Est & $\begin{array}{l}\text { GCTAAACCAGTAG/AGGTCTTCAAAA } \\
\text { CCCGGTACAG/AGCAGGATTACAACA }\end{array}$ & 147 & 57 \\
\hline 2. & ETEC & Elt & $\begin{array}{l}\text { CACACGGAGCTCCTCAGTC } \\
\text { CCCCCAGCCTAGCTTAGTTT }\end{array}$ & 508 & $57^{\circ}$ \\
\hline 3. & EPEC & Eae & $\begin{array}{l}\text { CCCGAATTCGGCACAAGCATAAGC } \\
\text { CCCGGATCCGTCTCGCCAGTATTCG }\end{array}$ & 881 & 57 \\
\hline 4. & EPEC & bfpA & $\begin{array}{l}\text { GGAAGTCAAATTCATGGGGG } \\
\text { GGAATCAGACGCAGACTGGT }\end{array}$ & 367 & 57 \\
\hline 5. & EHEC & stx1 & $\begin{array}{l}\text { CAACACTGGATGATCTCAG } \\
\text { CCCCCTCAACTGCTAATA }\end{array}$ & 350 & 57 \\
\hline 6. & EHEC & Stx2 & $\begin{array}{l}\text { ATCAGTCGTCACTCACTGGT } \\
\text { CTGCTGTCACAGTGACAAA }\end{array}$ & 110 & 57 \\
\hline 7. & EAEC & East & $\begin{array}{l}\text { CACAGTATATCCGAAGGC } \\
\text { CGAGTGACGGCTTTGTAG }\end{array}$ & 94 & 53 \\
\hline 8. & EIEC & ipaH & $\begin{array}{l}\text { CTCGGCACGTTTTAATAGTCTGG } \\
\text { GTGGAGAGCTGAAGTTTCTCTGC }\end{array}$ & 933 & 55 \\
\hline 9. & EIEC & $\operatorname{vtrF}$ & $\begin{array}{l}\text { AGCTCAGGCAATGAAACTTTGAC } \\
\text { TGGGCTTGATATTCCGATAAGTC }\end{array}$ & 618 & 55 \\
\hline 10. & DAEC & daaE & $\begin{array}{l}\text { GAACGTTGGTTAATGTGGGGTAA } \\
\text { TATTCACCGGTCGGTTATCAGT }\end{array}$ & 542 & 55 \\
\hline
\end{tabular}


Table 2.Distribution of Different Enteric Pathogens in Cases and Controls

\begin{tabular}{|c|c|c|}
\hline Pathogen Isolated & Cases ( $\mathbf{N}=\mathbf{3 5 0}) \mathbf{n}(\%)$ & Controls (N = 100) $\mathbf{n}(\%)$ \\
\hline Escherichia coli & $245(70)$ & $30(30)$ \\
\hline Vibrio cholera & $3(0.8)$ & $0(0)$ \\
\hline Shigella Spp. & $2(0.6)$ & $0(0)$ \\
\hline Cyst of Giardia lamblia & $10(2.9)$ & $0(0)$ \\
\hline Ova of Ancyclostoma duodenale & $6(1.7)$ & $0(0)$ \\
\hline Ova of Ascaris lumbricoides & $4(1.1)$ & $0(0)$ \\
\hline Total & $270(77.1)$ & $30(30)$ \\
\hline
\end{tabular}

Table 3.Distribution of Diarrheagenic Escherichia Coli (DEC)

\begin{tabular}{|c|c|c|c|}
\hline & Cases $\mathbf{n}(\%)$ & Controls $\mathbf{n}(\%)$ & Significance \\
\cline { 1 - 2 } PCR +ve & $26(10.6)$ & $1(3.3)$ & \multirow{2}{*}{$\begin{array}{c}\text { Chi square }=1.599 \\
\text { P value }=0.0205\end{array}$} \\
\hline PCR -ve & $219(89.4)$ & $29(96.7)$ & $30(100)$ \\
\hline Total & $245(100)$ & \\
\hline
\end{tabular}

Table 4.Age and Gender Wise Distribution of DEC in Cases $(\mathbf{N}=26)$

\begin{tabular}{|c|c|c|c|}
\hline Age (in years) & Male & Female & Total $\mathbf{n}$ (\%) \\
\hline $0-1$ & 7 & 5 & $12(46.2)$ \\
\hline $1-5$ & 9 & 2 & $11(42.3)$ \\
\hline $5-14$ & 2 & 1 & $3(11.5)$ \\
\hline Total & $18(69.2 \%)$ & $8(30.8 \%)$ & $26(100)$ \\
\hline
\end{tabular}

Table 5.Distribution of Different Pathotypes of DEC

\begin{tabular}{|c|c|c|c|c|}
\hline $\begin{array}{c}\text { S. } \\
\text { No. }\end{array}$ & $\begin{array}{c}\text { Presence of virulence } \\
\text { gene (either singly or in } \\
\text { combination) }\end{array}$ & $\begin{array}{c}\text { Interpretation of } \\
\text { specific DEC pathotype }\end{array}$ & $\begin{array}{c}\text { Number of isolates in } \\
\text { cases (N = 26) } \\
\mathbf{n}(\%)\end{array}$ & $\begin{array}{c}\text { Number of isolates in } \\
\text { controls (N = } \mathbf{~}) \\
\mathbf{n}(\mathbf{\%})\end{array}$ \\
\hline 1. & est and elt & ETEC & $14(53.8)$ & $1(100)$ \\
\hline 2. & eae, bfpA & EPEC & $10(38.5)$ & $0(0)$ \\
\hline 3. & stx1 and stx2 & EHEC & $2(7.7)$ & $0(0)$ \\
\hline 4. & east & EAEC & $0(0)$ & $0(0)$ \\
\hline 5. & IpaH and vtrF & EIEC & $0(0)$ & $0(0)$ \\
\hline 6. & daaE & DAEC & $0(0)$ & $0(0)$ \\
\hline Total & & & $26(100)$ & $1(100)$ \\
\hline
\end{tabular}

Of the 350 cases, 245 (70\%) were E. coli were isolated, from which diarrheagenic $E$. coli were identified in $26(7.4 \%)$ cases by one or more of the laboratory test methods (Phenoytypic methods like serology and genotypic method like PCR). Similarly, in the control group (100), E. coli were isolated in 30 cases, where diarrheagenic E. coli was identified in one only. On comparison of the results between cases and control, the occurrence of DEC was found to be statistically significant in cases ( $p$ value $=0.0205)($ Table 3$)$.

Maximum number of DEC i.e. 12 (46.2\%) were distributed in 0-1 year age group followed by 1-5 year of age group i.e. $11(42.3 \%)$ and least in the $5-14$ years of age group i.e. $3(11.5 \%)$. Male and female distribution of DEC were 18 $(69.2 \%)$ and $8(30.8 \%)$, respectively (Table 4$)$.

Out of 26 DEC from cases, ETEC was found to be highest in number i.e. 14 (53.8\%) followed by EPEC and EHEC i.e. $10(38.5 \%)$ and $2(7.7 \%)$ respectively. No isolate was found to be EAEC, EIEC and DAEC pathotypes. From the control group, only one diarrheagenic strain was found to be ETEC type (Table 5). 
Table 6.Frequency of Common Associated Signs and Symptoms and Risk Factors with DEC Positive Cases

\begin{tabular}{|c|c|c|c|c|c|c|c|}
\hline \multirow{2}{*}{\multicolumn{2}{|c|}{ C/F ETEC (14) }} & \multicolumn{6}{|c|}{ No (\%) of Diarrheagenic E. coli Pathotype } \\
\hline & & EPEC (10) & EHEC (2) & EIEC & EAEC & DAEC & \\
\hline \multicolumn{2}{|c|}{ Vomiting } & 9 & 8 & 1 & - & - & - \\
\hline \multicolumn{2}{|c|}{ Fever } & 10 & 9 & 1 & - & - & - \\
\hline \multicolumn{2}{|c|}{ Abdominal pain } & 5 & 5 & 2 & - & - & - \\
\hline \multirow[t]{2}{*}{ Type of diarrhoea } & Watery & 11 & 7 & 1 & - & - & - \\
\hline & Mucoid & 2 & 3 & 0 & - & - & - \\
\hline \multicolumn{3}{|c|}{ Bloody 1} & 0 & 1 & - & - & - \\
\hline \multirow{3}{*}{$\begin{array}{c}\text { Level of } \\
\text { dehydration }\end{array}$} & Severe & 10 & 5 & 0 & - & - & - \\
\hline & Some & 3 & 2 & 1 & - & - & - \\
\hline & No & 2 & 2 & 1 & - & - & - \\
\hline \multirow{3}{*}{ Feeding habit } & $\begin{array}{c}\text { Exclusive } \\
\text { breastfeeding (EB) }\end{array}$ & 0 & 0 & 0 & - & - & - \\
\hline & $\begin{array}{l}\text { Breastfeeding }+ \\
\text { Formula fed }(B, F)\end{array}$ & 4 & 7 & 1 & - & - & - \\
\hline & Solid food (S) & 10 & 3 & 1 & - & - & - \\
\hline
\end{tabular}

The most common associated symptoms in cases with DEC was fever i.e. 20 (76.9\%) followed by watery diarrhoea in 19 (73.1\%) and vomiting in 18 (69.2\%). EPEC pathotype was commonly associated with fever $(9 / 10)$ and ETEC was associated with vomiting and watery diarrhoea i.e. 9/14 and $11 / 14$ respectively. Maximum numbers of cases i.e. $14(53.8 \%)$ with DEC were on a solid diet and the rest i.e. $12(46.2 \%)$ were on a combination of formula feed and breastfeed. Diarrheagenic $E$. coli strains were not isolated from cases that were exclusively breastfed (Table 6).

Table 7.Seasonal Distribution of Isolated Diarrheagenic E. coli

\begin{tabular}{|c|c|}
\hline Season & $\begin{array}{c}\text { Cases with Diarrheagenic } \\
\text { E. coli (N = 26) } \mathbf{n} \text { (\%) }\end{array}$ \\
\hline July-October (Rainy) & $18(69.2)$ \\
\hline $\begin{array}{c}\text { November-February } \\
\text { (Winter) }\end{array}$ & $2(7.7)$ \\
\hline March-June (Summer) & $6(23.1)$ \\
\hline
\end{tabular}

Diarrheagenic E. coli were more common i.e. $18(69.2 \%)$ during the rainy season and least common i.e. 2 (7.7\%) during the winter season (Table 7).

\section{Discussion}

Diarrhoea is a global health problem, but is especially prevalent in developing countries due to poor environmental sanitation, inadequate water supplies, poverty and lack of health education. ${ }^{29}$ It causes 1.5 million deaths every year and remains 2 nd only following respiratory diseases to cause under 5 mortality. ${ }^{4,6}$ In India, diarrhoea is the third most common cause of childhood mortality and is responsible for $13 \%$ of all deaths/year in children younger than 5 years old. ${ }^{30}$ In developing countries, due to breaches in safe water supply and poor hygiene, $E$. coli is the most common cause of diarrhoea among children living in these areas, the other most common causative agents being Rotavirus; whereas in developed countries Campylobacter spp. is responsible for a majority of the cases of diarrhoea. ${ }^{31}$ Diarrheagenic $E$. coli (DEC) cause a wide variety of gastrointestinal diseases, particularly among children in developing countries, resulting in significant morbidity and mortality. ${ }^{32}$ This prospective case-control study was conducted from October 2014 to September 2016 to identify the different pathotypes of DEC in paediatric group, and factors affecting the incidence of diarrhoea due to different types of diarrheagenic $E$. coli.

In the present study out of the 350 stool samples from diarrheal cases, bacterial isolates and parasitic cysts and ova are detected in 277 (77.1\%). Of these 245 (70\%) were E. coli, $3(0.8 \%)$ V. cholerae and $2(0.6 \%)$ were Shigella species. Among the parasitic pathogens, cysts of Giardia lamblia were detected in 10 (2.9\%) and ova of Ancyclostoma duodenale and Ascaris lumbricoides in 6 (1.7\%) and 4 (1.1\%) cases respectively. Out of 100 controls, E. coli was isolated in $30 \%$ of cases and other bacterial pathogens, parasitic cysts or ova were not observed (Table 1). The result is well correlated with other studies. ${ }^{33,34}$

Out of 350 cases of diarrhoea in the present study, 26 (7.4\%) 
cases were diagnosed to be associated with diarrheagenic Escherichia coli and 1 (1\%) diarrheagenic Escherichia coli was isolated from the control group of 100 . Our result is well correlated with the study of Chomvarin C, et al. who also reported an isolation rate of $7.9 \%$ of DEC from diarrhoeal cases. However, Dutta S, et al., Hegde A et al. and Allam A et al. reported a higher prevalence of DEC i.e. $11.8 \%, 26 \%$ and $24.4 \%$ in cases and $2.3 \%, 8 \%$ and $3.3 \%$ in controls respectively. ${ }^{34-38}$ The results of the cases, when compared to control was found to be statistically significant ( $p$ value $=0.0205$ ) and in concordance with other studies. ${ }^{34,38}$ This difference in isolation rate of diarrheagenic $E$. coli may be due to the fact that the prevalence of DEC varies around the world from region to region and even between countries.

In our study, diarrheagenic $E$. coli were more common in males i.e. 18 (69.2\%) as compared to females (8, 30.8\%) which is in accordance with the study previously done by others. ${ }^{39,40}$ The age distributions of diarrheagenic $E$. coli among the diarrheal children were observed varyingly in the three age groups in the present study. Maximum DEC pathotypes i.e. 12 (46.2\%) were detected in the 0-1 year of age groups followed by 1-5 years of age group i.e. 11 $(42.3 \%)$ and least i.e. $3(11.5 \%)$ in $5-14$ years of age group. The age distribution of different DEC pathotypes is similar to the study by Ifeanyi $C$, et al., who reported $51.6 \%$ of diarrheagenic $E$. coli belonged to the age group of $0-1$ year and the rest $49.4 \%$ belonged to more than 1 year of age group. However, Dutta $S$, et al. in their study found that the maximum number of DEC i.e. $45.6 \%$ belonged to $<2$ years of age followed by $5-14$ years age group and $2-5$ years of age group. ${ }^{35,41}$ The difference in the inclusion criteria of study population in different studies may contribute to the difference in the distribution of various pathotypes of DEC.

Three pathotypes of DEC (ETEC, EPEC and EHEC) were detected in children with diarrhoea by multiplex PCR in the present study. The most prevalent pathotype of diarrheagenic $E$. coli isolated was ETEC (53.8\%) which is similar to the result of the study done by Allam AA, et al. and Suganya D, et. al. who reported ETEC as the most common pathotype. ${ }^{38,42}$ The result of the present study differs from the studies done by Hegde A et al. Moshtagian F, et al., Dutta $S$, et al. who reported that EAEC (50\%), EPEC $(63.2 \%)$ and EAEC (48.7\%) respectively as the commonest pathotype. ${ }^{36,37,43}$ In this study, we did not detect any EAEC, EIEC or DAEC strain from cases. In the control group, only 1 DEC was isolated which was identified as ETEC type. The variation in the detection rates of the different DEC pathotypes, reported in present and previously mentioned studies can be attributed to several factors like geographical locations, social status, dietary behaviour, housing, and quality of sanitation.

The DEC positive diarrhoeal cases in the current study showed fever $(76.9 \%)$ to be the commonest symptom followed by watery diarrhoea (73.1\%) and vomiting (69.2\%). Audu $\mathrm{R}$ et al. also observed fever as the commonest symptom (68\%) followed by vomiting $(60 \%)$ in cases with DEC. ${ }^{44}$ On comparison of different pathotypes with particular associated symptoms in our study, it was found that the EPEC pathotype was commonly associated with fever ( 9 out of 10) and vomiting and watery diarrhoea was commonly associated with ETEC type (9 out of 14 and 11 out of 14 respectively) which accounts for a severe degree of dehydration (10 out of 14). Dutta S, et al. reported the association of EPEC and ETEC type with vomiting, watery diarrhoea and severe dehydration. ${ }^{35}$ Out of the 2 EHEC isolates in our study, one was from a case, who had nonbloody stool. This occurrence further stresses on the fact that non-bloody diarrhoea does not rule out EHEC infection. Maximum number 14 (53.8\%) of DEC were isolated from cases on solid food habit followed by $12(46.2 \%)$ cases who were on a combination of formula feed and breastfeeding, which is similar to the study by Ifeanyi $C$, et al. who reported that DEC infection was highest in children fed with solid food $(64.1 \%)$ followed by those on a combination of breast milk and formula feed (34.3\%). ${ }^{41}$ No DEC was isolated from exclusively breastfed children in our study. It may be due to the fact that breastfeeding has been observed to protect the infant from the morbidity and mortality of diarrhoea in the first few months of life and when given exclusively, it offers the greatest protection. ${ }^{45}$

This study showed diarrheagenic $E$. coli were more commonly i.e. $18(69.2 \%)$ isolated in the rainy season followed by summer i.e. 6 (23.1\%) and least i.e. 2 (7.7\%) in winter. This result is similar to the study done by Samal SK, et al. and Faruque AS, et al. ${ }^{46,47}$ But the result differs from the study by Dutta $S$, et al. who reported that DECmediated diarrhoea is not specific to any season and is found throughout the year. Moyo JS, et al. in their study in Tanzania showed that $64.1 \%$ of DEC cases were isolated during the summer season. ${ }^{35,48}$ These variations in the isolation rate of DEC in different seasons reported by various authors may be due to the fact that environmental parameters such as temperature and humidity within a specific geographical region are the important factors associated with seasonal variations.

\section{Limitations of the Study}

It is a tertiary care hospital-based study, so at the time of admission, many of the patients had already received antibiotics which could have modified the underlying original symptoms, which is a limitation of our study. Another limitation of the present study is that some confounding factors like different parameters of nutritional level, Vit. A level and immunisation status could not be assessed/ estimated because of limited resources. 
If it were a community-based study, more samples from the symptomatic group could have been included in the study; which could have reflected the real prevalence of diarrheagenic E. coli.

\section{Conclusion}

This study concludes that proper knowledge of the aetiology of childhood diarrhoea could help in the initiation of correct management protocol and reduce the morbidity related to diarrhoea. It emphasises the implementation of proper history taking, collection of demographic data, data regarding dietary habits and inclusion of identification of diarrheagenic $E$. coli in routine diagnostic procedures, particularly in paediatric diarrh0eal cases as DEC are the most common bacterial agents associated with childhood diarrhoea. It also emphasises encouraging exclusive breastfeeding as it has proven to have a protective role in preventing DEC related diarrhoea in infants.

Research may be taken up in large community based geographical areas to corroborate these findings and preventive measures including a new vaccine against DEC may be the need of the hour.

\section{Source of Funding: No extramural funding Conflict of Interest: None}

\section{References}

1. Saka HK, Dabo NT, Muhammad B, García-Soto S, Ugarte-Ruiz M, Alvarez J. Diarrheagenic Escherichia coli pathotypes from children younger than 5 years in Kano State, Nigeria. Front Public Health. 2019;7:348. [PubMed] [Google Scholar]

2. Global Burden of Disease Pediatrics Collaboration; Kyu HH, Pinho C, Wagner JA, Brown JC, Bertozzi-Villa A, Charlson FJ, Coffeng LE, Dandona L, Erskine HE, Ferrari AJ, Fitzmaurice C, Fleming TD, Forouzanfar $\mathrm{MH}$, Graetz N, Guinovart C, Haagsma J, Higashi H, Kassebaum NJ, Larson HJ, Lim SS, Mokdad AH, MoradiLakeh M, Odell SV, Roth GA, Serina PT, Stanaway JD, Misganaw A, Whiteford HA, Wolock TM, Wulf Hanson S, Abd-Allah F, Abera SF, Abu-Raddad $\amalg$, AlBuhairan FS, Amare AT, Antonio CA, Artaman A, Barker-Collo SL, Barrero LH, Benjet C, Bensenor IM, Bhutta ZA, Bikbov $B$, Brazinova A, Campos-Nonato I, Castañeda-Orjuela CA, Catalá-López F, Chowdhury R, Cooper C, Crump JA, Dandona R, Degenhardt L, Dellavalle RP, Dharmaratne SD, Faraon EJ, Feigin VL, Fürst T, Geleijnse JM, Gessner BD, Gibney KB, Goto A, Gunnell D, Hankey GJ, Hay RJ, Hornberger JC, Hosgood HD, Hu G, Jacobsen $\mathrm{KH}$, Jayaraman SP, Jeemon P, Jonas JB, Karch A, Kim D, Kim S, Kokubo Y, Kuate Defo B, Kucuk Bicer B, Kumar GA, Larsson A, Leasher JL, Leung R, Li Y, Lipshultz SE, Lopez $A D$, Lotufo PA, Lunevicius R, Lyons RA, Majdan $M$, Malekzadeh R, Mashal T, Mason-Jones AJ, Melaku YA,
Memish ZA, Mendoza W, Miller TR, Mock CN, Murray J, Nolte S, Oh IH, Olusanya BO, Ortblad KF, Park EK, Paternina Caicedo AJ, Patten SB, Patton GC, Pereira DM, Perico N, Piel FB, Polinder S, Popova S, Pourmalek F, Quistberg DA, Remuzzi G, Rodriguez A, Rojas-Rueda $D$, Rothenbacher D, Rothstein DH, Sanabria J, Santos IS, Schwebel DC, Sepanlou SG, Shaheen A, Shiri R, Shiue I, Skirbekk V, Sliwa K, Sreeramareddy CT, Stein DJ, Steiner TJ, Stovner LJ, Sykes BL, Tabb KM, Terkawi AS, Thomson AJ, Thorne-Lyman AL, Towbin JA, Ukwaja KN, Vasankari T, Venketasubramanian N, Vlassov VV, Vollset SE, Weiderpass E, Weintraub RG, Werdecker A, Wilkinson JD, Woldeyohannes SM, Wolfe CD, Yano Y, Yip P, Yonemoto N, Yoon SJ, Younis MZ, Yu C, El Sayed Zaki M, Naghavi M, Murray CJ, Vos T. Global and national burden of diseases and injuries among children and adolescents between 1990 and 2013: findings from the global burden of disease 2013 study. JAMA Pediatr. 2016;170:267-87. [PubMed] [Google Scholar]

3. Lanata CF, Fischer-Walker CL, Olascoaga AC, Torres CX, Aryee MJ, Black RE; Child Health Epidemiology Reference Group of the World Health Organization and UNICEF. Global causes of diarrheal disease mortality in children $<5$ years of age: a systematic review. PLoS One. 2013;8:e72788. [PubMed]

4. Parashar U, Bresee JS, Glass RI. The global burden of diarrhoeal disease in children. Bull World Health Organ. 2003;81(4):236. [Google Scholar]

5. Kirk MD, Pires SM, Black RE, Caipo M, Crump JA, Devleesschauwer B, Döpfer D, Fazil A, Fischer-Walker CL, Hald T, Hall AJ, Keddy KH, Lake RJ, Lanata CF, Torgerson PR, Havelaar AH, Angulo FJ. World Health Organization estimates of the global and regional disease burden of 22 foodborne bacterial, protozoal, and viral diseases, 2010: a data synthesis. PLoS Med. 2015;12:e1001921. [PubMed] [Google Scholar]

6. Kosek M, Bern C, Guerrant RL. The global burden of diarrhoeal disease, as estimated from studies published between 1992 and 2000. Bull World Health Organ. 2003;81(3):197-204. [PubMed] [Google Scholar]

7. Hien BT, Trang DT, Scheutz F, Cam PC, Mølbak K, Dalsgaard A. Diarrhoeagenic Escherichia coli and other causes of childhood diarrhoea: a case-control study in children living in a wastewater-use area in Hanoi, Vietnam. J Med Microbiol. 2007;56(Pt 8):1086-96. [PubMed] [Google Scholar]

8. Robins-Browne RM, Bordun AM, Tauschek M, BennettWood VR, Russell J, Oppedisano F, Lister NA, Bettelheim KA, Fairley CK, Sinclair MI, Hellard ME. Escherichia coli and community-acquired gastroenteritis, Melbourne, Australia. Emerg Infect Dis. 2004;10:1797-805. [PubMed] [Google Scholar]

9. Okeke NI. Diarrheagenic Escherichia coli in sub-Saharan 
Africa: status, uncertainties and necessities. J Infect Dev Ctries. 2009;3(11):817-42. [PubMed] [Google Scholar]

10. Lakshminarayanan $S$, Jayalakshmy R. Diarrheal diseases among children in India: Current scenario and future perspectives, J Nat Sci Biol Med. 2015 Jan-Jun; 6(1): 24-28. [Google Scholar]

11. Verma S, Kumar V, Singh P. Managing childhood diarrhoea at homes in India: an opportunity to reduce child morbidity and mortality. Infect Dis Health. 2016;21(4):176-83. [Google Scholar]

12. Keusch GT, Walker CF, Das JK, Horton S, Habte D. Diarrheal diseases. In: Black RE, Laxminarayan R, Temmerman $\mathrm{M}$, Walker $\mathrm{N}$, editors. Washington, $\mathrm{DC}$ : World Bank; 2016.

13. John J, Sarkar R, Muliyil JBN, Bhan MK, Kang G. Rotavirus gastroenteritis in India, 2011-2013: Revised estimates of disease burden and potential impact of vaccines. Vaccine. 2014;32S:A5-9. [PubMed] [Google Scholar]

14. Bhandari N, Rongsen-Chandola T, Bavdekar A, John J, Antony K, Taneja S, Goyal N, Kawade A, Kang G, Rathore SS, Juvekar S, Muliyil J, Arya A, Shaikh H, Abraham V, Vrati S, Proschan M, Kohberger R, Thiry G, Glass R, Greenberg HB, Curlin G, Mohan K, Harshavardhan GV, Prasad S, Rao TS, Boslego J, Bhan MK; India Rotavirus Vaccine Group. Efficacy of a monovalent humanbovine (116E) rotavirus vaccine in Indian infants: a randomised double blind placebo controlled trial. Lancet. 2014;383:2136-43. [PubMed] [Google Scholar]

15. Kahn G, Fitzwater S, Tate J, Kang G, Ganguly N, Nair G, Steele D, Arora R, Chawla-Sarkar M, Parashar $U$, Santosham M. Epidemiology and prospects for prevention of rotavirus disease in India. Indian Pediatr. 2012;49:467-74. [PubMed] [Google Scholar]

16. Clark A, Zandvoort KV, Flasche S, Sanderson C, Bines J, Tate J, Parashar U, Jit M. Efficacy of live oral rotavirus vaccines by duration of follow-up: a meta-regression of randomised controlled trials. Lancet Infect Dis. 2019;19(7):717-27. [PubMed] [Google Scholar]

17. Al-Gallas N, Bahari O, Bouratbeen A, Hasen AB, Aissa RB. Etiology of acute diarrhea in children and adults in Tunis, Tunisia, with emphasis on diarrheagenic Escherichia coli; prevalence, phenotyping \& molecular epidemiology. Am J Trop Med Hyg. 2007;77:571-82. [PubMed] [Google Scholar]

18. Gomes TA, Rassi V, Mac Donald KL, Ramos SR, Trabulsi LR, Vieira MA, Guth BE, Candeias JA, Ivery C, Toledo $M R$, Blak PA. Enteropathgene associated with acute diarrheal disease in urban infants in Sao Paulo, Brazil. J Infect Dis. 1991;164:331-7. [PubMed] [Google Scholar]

19. Kaper JB, Nataro JP, Mobley HL. Pathogenic Escherichia coli. Nat Rev Microbiol. 2004;2:123-40. [PubMed] [Google Scholar]

20. Chandra M, Cheng P, Rondeau G, Porwollik S, McClelland
M. A single step multiplex PCR for identification of six diarrheagenic E. coli pathotypes and Salmonella. Int J Med Microbiol. 2013;303:210-6. [PubMed] [Google Scholar]

21. Rich C, Alfidja A, Sirot J, Joly B, Forestier C. Identification of human enterovirulent Escherichia coli strains by multiplex PCR. J Clin Lab Anal. 2001;15:100-3. [PubMed] [Google Scholar]

22. Miliwebsky E, Schelotto F, Varela G, Luz D, Chinen I, Piazza RMF. Human diarrheal infections: diagnosis of diarrheagenic Escherichia coli pathotypes. In: Torres AG, editor. Escherichia coli in the Americas. Switzerland: Springer International Publishing; 2016. p.343-69. [Google Scholar]

23. Croxen MA, Law RJ, Scholz R, Keeney KM, Wlodarska $M$, Finlay $B B$. Recent advances in understanding enteric pathogenic Escherichia coli. Clin Microbiol Rev. 2013;26(4):822-80. [PubMed] [Google Scholar]

24. Rajendran $P$, Ajjampur SS, Chidambaram D, Chandrabose G, Thangaraj B, Sarkar R, Samuel P, Rajan DP, Kang G. Pathotypes of diarrheagenic Escherichia coli in children attending a tertiary care hospital in South India. Diagn Microbiol Infect Dis. 2010;68:117-22. [PubMed] [Google Scholar]

25. Nataro JP, Kaper JB. Diarrheagenic Escherichia coli. Clin Microbiol. 1998;11:142-201. [PubMed] [Google Scholar]

26. World Health Organization [Internet]. Diarrhoeal disease; 2017 [cited 2018 Dec 19]. Available from: https://www.who.int/news-room/fact-sheets/detail/ diarrhoeal-disease

27. World Health Organization. Manual for laboratory investigation of acute enteric infections. CDD/83.3. WHO, Geneva, Switzerland; 1987.

28. Purwar S, Bhattacharya D, Metgud SC, Kumar D, Chitambar SD, Roy S. A cross-sectional study on aetiology of diarrhoeal disease, India. Indian J Med Microbiol. 2016;34(3):375-9. [PubMed] [Google Scholar]

29. Briend A, Hasan KZ, Aziz KM, Hoque BA. Are diarrhea control programmes likely to reduce childhood malnutrition? Observations from rural Bangladesh. Lancet. 1989;2(8658):319-22. [PubMed] [Google Scholar]

30. Lakshminarayanan S, Jayalakshmy R. Diarrhoeal diseases among children in India: current scenario and future perspectives. J Nat Sci Biol Med. 2015;6(1):24-8. [PubMed] [Google Scholar]

31. Scallan E, Hoekstra RM, Angulo FJ, Tauxe RV, Widdowson M, Roy SL, Griffin PM. Foodborne Illness Acquired in the United States-Major Pathogens. Emerging Infectious Diseases. 2011;17(1):7-15. https://doi.org/10.3201/ eid1701.p11101. 
32. Dhanashree BS, Roy S, Sunaifa M. Prevalence of Enteropathogenic Escherichia coli (EPEC) in adult diarrhea cases and their antibiotic susceptibility pattern. Bri Microb Res J. 2015;5:560-66. [Google Scholar]

33. Nguyen TV, Van LV, Huy CL, Gia KN, Weintraub A. Detection and characterization of diarrheagenic Escherichia coli from Young Children in Hanoi, Vietnam. J Clin Microbiol. 2005;43(2):755-60. [PubMed] [Google Scholar]

34. Dutta S, Guin S, Ghosh S, Pazhani GP, Rajendran K, Bhattacharya MK, Takeda Y, Nair GB, Ramamurthy T. Trends in the prevalence of diarrheagenic Escherichia coli among hospitalized diarrheal patients in Kolkata, India. PLoS One. 2013;8(2):e56068. [PubMed] [Google Scholar]

35. Hegde A, Ballal M, Shenoy S. Detection of diarrheagenic Escherichia coli by multiplex PCR. Indian J Med Microbiol. 2012;30(3):279-84. [PubMed] [Google Scholar]

36. Chomvarin C, Ratchtrachenchai OA, Chantarasuk Y, Srigulbutr S, Chaicumpar K, Namwat W, Kotimanusvanij D. Characterization of diarrheagenic Escherichia coli isolated from food in Khon Kaen, Thailand. Southeast Asian J Trop Med Public Health. 2005;36(4):931-9. [PubMed] [Google Scholar]

37. Allam AA, Amer A, Fahmy K, Siam AG. Rapid diagnosis and characterization of diarrheagenic Escherichia coli In Egyptian children using multiplex PCR. Egyptian J Med Microbiol. 2006;15(3):523-30. [Google Scholar]

38. Gautam K, Pokhrel BM, Shrestha CD, Bhatia DR. Prevalence of diarrheagenic E. coli (DEC) determined by polymerase chain reaction (PCR) in different tertiary care hospitals in Nepal. JSM Microbiol. 2015;3:1021-7.

39. Aly MEA, Essam TM, Amin MA. Involvement of virulence genes and antibiotic resistance in clinical and food borne diarrheagenic Escherichia coli isolates from Egypt. World J Med Sc. 2012;7(4):276-84.

40. Ifeanyi C, Ikeneche NF, Bassey B, Al-Gallas N, Aissa RB, Boudabous A. Diarrheagenic Escherichia coli pathotypes isolated from children with diarrhea in the Federal Capital Territory Abuja, Nigeria. J Infect Dev Ctries. 2015;9(2):165-74. [PubMed] [Google Scholar]

41. Suganya D, Kanimozhi K, Panneerselvam A, Dhanapau K. Molecular Characterization of Diarrheagenic Escherichia coli from Tiruchirappalli District, Tamilnadu, India. Int J Curr Microbiol App Sci. 2016;5(3):478-84.

42. Moshtagian F, Alipour M, Yahyapour Y. Prevalence of Escherichia coli pathotypes among children with diarrhea in Babol, Northern Iran. Int J Enteric Pathog. 2016;4(3): e36326. [Google Scholar]

43. Audu R, Omiliabu S, Renner J, Awodiji J. Risk factors, clinical features and management of children with diarrhea in Lagos. J Niger Assoc Infect Control. 2000;3:24-9. [Google Scholar]

44. Gracey M. Diarrhea and malnutrition: a challenge for pediatricians. J Pediatr Gastroenterol Nutr. 1996;22(1):6-16. [PubMed] [Google Scholar]

45. Samal SK, Khuntia HK, Nanda PK, Satapathy CS, Nayak SR, Sarangi AK, Sahoo N, Pattnaik SK, Chhotray GP, Pal $B B$. Incidence of bacterial enteropathogens among hospitalised diarrhea patients from Orissa, India. Jpn J Infect Dis. 2008;61(5):350-5. [PubMed] [Google Scholar]

46. Faruque AS, Salam MA, Faruque SM, Fuchs GJ. Aetiological, clinical and epidemiological characteristics of a seasonal peak of diarrhoea in Dhaka, Bangladesh. Scand J Infect Dis. 1998;30(4):393-6. [PubMed] [Google Scholar]

47. Moyo SJ, Maselle SY, Matee MI, Langeland N, Mylvaganam $\mathrm{H}$. Identification of diarrheagenic Escherichia coli isolated from infants and children in Dar es Salaam, Tanzania. BMC Infect Dis. 2007;7:92. [PubMed] [Google Scholar] 